\section{MS14-P3 High-temperature behaviour of astrophyllite and magnesioastrophyllite from Khibiny massif (Kola peninsula, Russia)}

Elena S. Zhitova ${ }^{1}$, Maria G. Krzhizhanovskaya ${ }^{1}$, Sergey V. Krivovichev $^{1,2}$, Victor N. Yakovenchuk ${ }^{2}$

1. Saint Petersburg State University

2. Nanomaterials research Centre, KSC, RAS

email: zhitova_es@mail.ru

The thermal behaviour of natural astrohyllite and magnesioastrophyllite (Khibiny massif, Kola peninsula, Russia) was studied using in situ high-temperature XRD in the range $25-1000{ }^{\circ} \mathrm{C}$ by means of Rigaku Ultima IV powder X-ray diffractometer $(\mathrm{CuK} \alpha)$ with a high-temperature camera. The first reflections of new high-temperature phase were detected at $500{ }^{\circ} \mathrm{C}$ and 550 ${ }^{\circ} \mathrm{C}$ for astrophyllite and magnesioastrophyllite, respectively. Peaks of new phase were shifted in the high-angle region. Reflections of both, initial minerals and its high-temperature phase presented in the diffraction pattern at the temperature of the phase transition. In the temperature range $525-775{ }^{\circ} \mathrm{C}$ only high-temperature phase remained. Both minerals decompose at $775^{\circ} \mathrm{C}$. Single crystal X-ray diffraction of astrophyllite was carried out for both phases using single-crystal diffractometer Bruker APEX II, MoK $\alpha$. Unit cell parameters of original astrophyllite are a = 5.3752(1), $\mathrm{b}=11.8956(3), \mathrm{c}=11.6554(3) \AA, \alpha=$ 113.157(2), $\beta=94.530(2), \gamma=103.112(2)^{\circ}, \mathrm{V}=$ $655.47(3) \AA 3$. Unit cell parameters of high-temperature phase are $\mathrm{a}=5.3287(4), \mathrm{b}=11.790(1), \mathrm{c}=11.4332(9) \AA$, $\alpha=112.530(8), \beta=94.539(6), \gamma=103.683(7)^{\circ}, \mathrm{V}=$ 633.01(9) ^3. Thermal behaviour of studied material changes from thermal expansion for initial phases to contraction for high-temperature phases. The decrease of the unit-cell parameters is probably the result of change of oxidation of iron that leads to the shortening of the Fe-O bond lengths.

The XRD studies have been performed at the X-ray Diffraction Centre of St. Petersburg State University.

This work was supported by the Russian Foundation for Basic Research (project no.14-05-31229), StSPbU internal grant № 3.37.222.2015 and the President of Russian Federation Grant for Young Candidates of Sciences (to AAZ, grant MK-3296.2015.5).

Keywords: thermal behaviour of natural layered titanosilicates, Kola alkaline massifs, astrophyllite
MS14-P4 Synthesis, structure and low temperature behaviour of

Sidorenkite/Bonshtedtite-like sodium carbonophosphates containing $\mathrm{Ni}(\mathrm{II}), \mathrm{Fe}(\mathrm{II})$ and $\mathrm{Mn}(\mathrm{II})$

Sephira Riva ${ }^{1}$, Serena Margadonna ${ }^{1}$

1. College of Engineering, Swansea University, SA2 8PP Swansea, UK

email: 839245@swansea.ac.uk

Recent predictions highlighted the promising features of sidorenkite $\left(\mathrm{Na}_{3} \mathrm{Mn}\left(\mathrm{PO}_{4}\right)\left(\mathrm{CO}_{3}\right)\right)^{-}$and bonshtedtite $\left(\mathrm{Na}_{3} \mathrm{Fe}\left(\mathrm{PO}_{4}\right)\left(\mathrm{CO}_{3}{ }^{3}\right)\right.$-like compounds for the development of new, low cost, Na-based batteries. These materials are characterized by high theoretical specific energy and stability at air exposure; moreover, they can undergo reversible $\mathrm{Na}$-ion intercalation/de-intercalation by changing the oxidation state of the central transition metal.

$\mathrm{Na} \mathrm{M}_{3}\left(\mathrm{PO}_{4}\right)\left(\mathrm{CO}_{3}\right)[\mathrm{M}=\mathrm{Ni}, \mathrm{Mn}, \mathrm{Fe}]$ were synthesised via hydrothermal synthesis. Temperature, starting concentrations, reaction time and stirring were modulated to obtain pure samples.

Compounds were characterised using synchrotron radiation (ID31 at the ESRF), with temperature ranging from $10 \mathrm{~K}$ to $290 \mathrm{~K}$. Data were collected in transmission mode by using $0.5 \mathrm{~mm}$ glass capillaries and scanning from 0 to $302 \theta(\lambda=0.39992 \AA)$.

Crystals were found to have monoclinic sidorenkite structure $(\mathrm{P} 2 / \mathrm{m})$. Each cell unit consists of a transition metal octahedron sharing four vertices with the tetrahedral $\mathrm{PO}_{4}$ group and an edge with the $\mathrm{CO}_{3}$ group. The connection of transition metal octahedra, $P O$ tetrahedra and planar $\mathrm{CO}_{3}$ groups create a two-dimensional subunit, which extends along the [lll 100$]$ plane. Sodium ions occupy two distinct interstitial positions between the double layers formed by tetrahedral $\mathrm{PO}_{4}$ groups and $\mathrm{MO}_{6}$ octahedra. These sites are coordinated by 7 (multiplicity 2) and 6 (multiplicity 4) oxygen atoms.

The dependence of cell volume and interatomic distances from temperature was quantified from cell parameters variations ( $a, b$ and $c$ lattice parameters; $\beta$ angle). The carbonophosphates structure was proven extremely stable, with no phase transitions occurring in the selected temperature region.

Magnetic properties tests highlighted the anti-ferromagnetic behaviour of $\mathrm{Ni}, \mathrm{Mn}$, and $\mathrm{Fe}$ carbonophosphates; as well as the existence of several magnetic transitions at temperatures lower than $10 \mathrm{~K}$. 


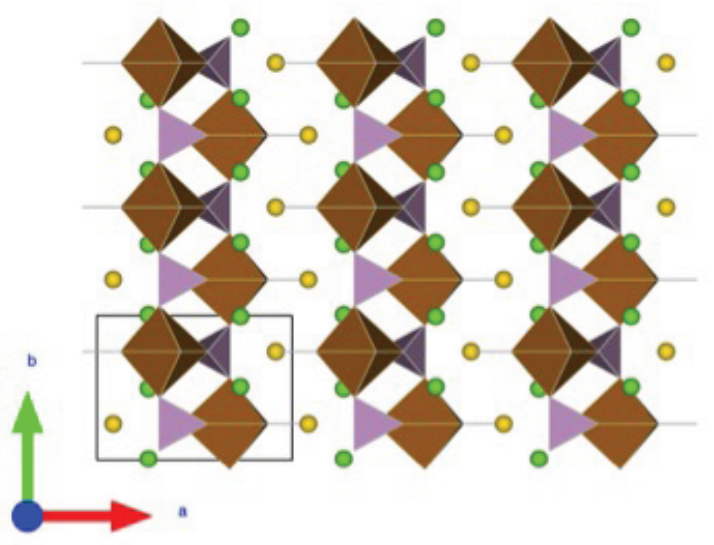

Figure 1. Structure of $\mathrm{Na}_{3} \mathrm{Fe}\left(\mathrm{PO}_{4}\right)\left(\mathrm{CO}_{3}\right)$ (bonshtedtite) viewed along $\left[\begin{array}{lll}0 & 0 & 1\end{array}\right]$ plane. $\mathrm{Fe}^{3}$ octahedra and $\mathrm{PO}_{4}$ tetrahedra are highlighted in brown and purple respectively. $\mathrm{Na}$ atoms occupying sites of multiplicity 2 (green) and 4 (yellow) are displayed. Oxygen atoms are hidden for clarity.

Keywords: Carbonophosphates, Low-temperature crystallography, SQUID
MS14-P5 Temperature and pressure induced phase transitions in chevkinite group. A joint XRD, XPS and EPMA structural studies

Marcin Stachowicz ${ }^{1}$, Krzysztof Woźniak ${ }^{1}$, Bogusław Bagiński ${ }^{2}$, Ray Macdonald ${ }^{2}$

1. Biological and Chemical Research Centre, Chemistry Department, University of Warsaw, Żwirki i Wigury 101, 02-089 Warsaw, Poland

2. Institute of Mineralogy, Geochemistry and Petrology, University of Warsaw, 02-089, al. Żwirki i Wigury 93, Warsaw, Poland

email: marcin.stachowicz@chem.uw.edu.pl

The chevkinite group of minerals (chevkinites and perrierites) are increasingly beingrecognized as accessory phases in a wide range of igneous and metamorphic rocks. The general formula for the most common members of the group, is $\mathrm{A}_{4} \mathrm{BC}_{2} \mathrm{D}_{2}\left(\mathrm{Si}_{2} \mathrm{O}_{7}\right)_{2} \mathrm{O}_{8}$, where the most common cations are $\mathrm{A}=\mathrm{Ca}^{2+}, \mathrm{REE}^{3+}, \mathrm{Sr}^{2+}, \mathrm{Th}^{4+} ; \mathrm{B}$, $\mathrm{C}, \mathrm{D}=\mathrm{Fe}^{2+}, \mathrm{Fe}^{3+}, \mathrm{Ti}^{4+}, \mathrm{Al}^{3+}, \mathrm{Mn}^{2+}, \mathrm{Mg}^{2+}$. Annealing at $750^{\circ} \mathrm{C}$ of niobian chevkinite-(Ce) single crystal from the Biraya rare-metal deposit (Russia) resulted in a phase transition from the space group $\mathrm{C} 2 / \mathrm{m}$ to $\mathrm{P} 2 / \mathrm{a}$. This may be of particular interest for researchers dealing with metamict minerals because annealing may lead to a slightly different crystal structure from the initial one, additionally a migration of cations to different crystallographic sites was observed during annealing. To confirm the new findings, next X-ray measurements on different unannealed and annealed crystals were performed.

A reversed effect of a phase transition was monitored on a single crystal of perrierite from Nettuno, Italy loaded into the diamond anvil cell. The compressibility of this mineral was analysed on the basis of fourteen X-ray diffraction (XRD) experiments from ambient pressure up to $6.4 \mathrm{GPa}$.

X-ray photoelectron spectroscopy (XPS) can give valuable results in the investigation of element valency especially when the amount of sample is insufficient for Mössbauer spectroscopy. This method can give information on any element and oxidation state, as long as the characteristic spectra for different ions are separated. This could provide crucial independent information allowing the establishment of the correct crystal structures of complex minerals. In Nb-bearing chevkinite-(Ce) iron is present as $\mathrm{Fe}^{2+}$ and $\mathrm{Fe}^{3+}$ and $\mathrm{Ti}$ is present as $\mathrm{Ti}^{4+}, \mathrm{Ti}^{3+}$ and possibly $\mathrm{Ti}^{2+}$. With this information the volumes of the first coordination spheres could be matched with the ionic radii of elements and their masses with site scattering factors in the analyzed crystal structures to obtain the most probable allocation of cations.

Empirical formulae for niobian chevkinite-(Ce) was established by joined XRD, XPS and EPMA analyses for $\mathrm{C} 2 / \mathrm{m}: \quad\left(\mathrm{Ce}_{1.9}{ }^{3+} \mathrm{La}_{1.2} \mathrm{Nd}_{0.4} \mathrm{Pr}_{0.2} \mathrm{Ca}_{0.1} \mathrm{Sr}_{0.1} \mathrm{Ba}_{0.1}\right) \quad \Sigma 4$ $\left(\mathrm{Fe}^{2+}{ }_{0.7} \mathrm{Ca}_{0.15} \mathrm{Mn}_{0.1} \mathrm{Th}_{0.05}\right)\left(\mathrm{Fe}^{3+}{ }_{0.7} \mathrm{Ti}_{0.5}{ }^{4+} \mathrm{Nb}_{0.6} \mathrm{Al}_{0.1} \mathrm{~V}_{0.1}\right)_{\sum 2}^{{ }^{24}}$ 